\title{
Implementasi Teknologi Tepat Guna Sebagai Upaya Preventif Penyebaran Covid-19
}

\author{
Hanifudin Sukri ${ }^{*}$ \\ ${ }^{1}$ Program Studi Teknik Elektro Fakultas Teknik Universitas Trunojoyo Madura \\ Jl. Telang No 02 Kamal Bangkalan Madura 69162 Jawa Timur \\ *E-mail : hanifudinsukri@trunojoyo.ac.id
}

DOI: https://doi.org/10.21107/pangabdhi.v7i2.8658

Naskah diterima 8 Mei 2021, Revisi 27 Agustus 2021, Terbit 29 Oktober 2021

\begin{abstract}
Abstrak
Covid-19 hingga saat ini belum terdapat obat spesifik, sementara obat yang digunakan untuk menyembuhkan pasien terpapar saat ini adalah kombinasi beberapa obat. Begitu pun dengan vaksin, virus ini belum ditemukan vaksinnya sampai saat ini. Maka dari itu, yang dapat dilakukan untuk meminimalisir terpapar Covid-19 ini yaitu dengan cara menghindarinya. Menurut World Health Organization (WHO) ada beberapa cara mencegah agar tidak tertular virus corona, yakni, sering mencuci tangan dengan sabun atau hand sanitizer, menjaga jarak dengan orang lain, hindari menyentuh mata dan hidung dan menggunakan masker. Melalui pengabdian masyarakat yang diselenggarakan oleh Lembaga Penelitian dan Pengabdian kepada Masyarakat (LPPM) UTM dengan tema implementasi teknologi tepat guna sebagai upaya preventif penyebaran covid-19. Harapan dari kegiatan dapat meningkatkan kesadaran masyarakat tentang bahaya covid-19 dan upaya pencegahan melalui implementasi teknologi tepat guna.
\end{abstract}

Kata Kunci : teknologi tepat guna, Covid-19, pengabdian masyarakat

\begin{abstract}
Covid-19 currently does not have a specific drug, while the drug used to treat exposed patients is a combination of several drugs. Likewise with vaccines, this virus has not been found for a vaccine until now. Therefore, what can be done to minimize exposure to Covid-19 is to avoid it. According to the World Health Organization (WHO) there are several ways to prevent you from contracting the corona virus, namely, washing your hands frequently with soap or hand sanitizer, keeping your distance from other people, avoiding touching your eyes and nose and using masks. Through community service organized by the UTM Research and Community Service Institute, service is carried out with the theme of implementing appropriate technology as an effort to prevent the spread of Covid-19. The hope of this activity can increase public awareness about the dangers of covid-19 and prevention efforts through the implementation of appropriate technology
\end{abstract}

Key Words : technology for community, Covid-19, community services

\section{PENDAHULUAN}

WHO telah menyatakan Corona Virus Disease 2019 (Covid-19) sebagai pandemi (WHO, 2020). Penyebaran Covid-19 semakin meluas, tidak terkecuali di Indonesia. Situasi ini berdampak besar terhadap semua aspek kehidupan masyarakat Indonesia, tidak terkecuali masyarakat di pedesaan. Mencermati banyaknya korban dari penyebaran Covid-19 di Indonesia yang semakin memprihatinkan sehingga diperlukan peran serta aktif semua lini dan upaya yang komprehensif dalam melakukan penanggulangan wabah ini. Sekaitan dengan hal ini, masih banyak masyarakat yang enggan mengikuti anjuran pemerintah ataupun badan kesehatan dalam melakukan tindakan preventif, bahkan cenderung mengentengkan bahaya Covid19 , sehingga dapat memperluas sebaran penularan Covid-19 (Arditama \& Lestari, 2020).

Akibat penularan virus corona yang sangat cepat inilah, organisasi kesehatan dunia (WHO) menetapkan virus corona sebagai pandemi pada 11 Maret 2020 (Widiyani, 2020). Saat ini wabah Covid-19 menjadi isu kesehatan yang paling menghebohkan seluruh dunia, termasuk Indonesia. Penanggulangan ekstrem seperti lockdown suatu daerah bahkan suatu negara pun dilakukan sebagai upaya untuk meminimalisir 
penyebaran penyakit tersebut. diameter virus corona diperkirakan mencapai 125 nanometer atau 0,125 mikrometer dimana satu mikrometer sama dengan 1000 nanometer. Ukuran tersebut kecil sekali dan tak mungkin pandangan manusia mampu melihatnya. Sekalipun sangat kecil dan manusia yang tak mau berpikir meremehkannya, virus ini mampu bertahan lebih dari 10 menit di permukaan, termasuk tangan. Bahkan WHO menyebut virus corona baru (Covid-19) dapat bertahan selama beberapa jam, bahkan beberapa hari dan dapat bertahan hidup di suhu 26-27 derajat celcius (Zahrotunnimah, 2020).

Data dari Provinsi Jawa Timur per tanggal 03 Juli 2020, virus corona telah menginfeksi 13.025 jiwa serta menyebabkan kematian 482 jiwa (Melani, 2020). Bahkan, Jawa Timur menempati provinsi urutan ketiga setelah DKI Jakarta dan Jawa Barat dalam jumlah kasus positif COVID-19 (Zamroni, 2020). Hal tersebut menunjukkan bahwa penyebaran virus Corona tersebut sangat cepat dan masif. Berbagai upaya telah dilakukan oleh pemerintah, mulai dari mengimbau langsung kepada masyarakat melalui pihak-pihak terkait seperti babinkamtibmas, membentuk kampung tangguh, jogo tonggo, maupun melakukan pembatasan sosial bersekala besar (PSBB) untuk menekan angka penularan, namun hal tersebut perlu dibarengi denga kesadaran masyarakat dalam menjaga sesama (Yunus \& Rezki, 2020).

Pencegahan penularan Covid-19 dapat dicegah dengan mengetrapkan Perilaku Hidup Bersih dan Sehat (PHBS), seperti cuci tangan dengan baik dan benar, menutup mulut saat batuk, serta menjaga kesehatan dan sistem kekebalan atau imunitas tubuh. Pengetahuan dan pemahaman masyarakat yang ilmiah, akurat dan dapat dipercaya dapat membantu untuk mempermudah penekanan penyebaran Covid-19 di Indonesia. Atas dasar inilah perlu dilakukan kegiatan pemberian informasi untuk meningkatkan pengetahuan masyarakat dalam menghadapi dan melewati pandemik Covid19 (Karo, 2012). Selain membekali masyarakat dengan pengetahuan tentang Covid-19, perlu juga diberikan sosialisasi tentang pentingnya untuk menghindari terinfeksi covid-19 yakni tentang pola hidup bersih dan sehat (PHBS) (Sulaeman \& Supriadi, 2020).

Pengabdian masyarakat (abdimas) merupakan kegiatan yang dilakukan dosen dan mahasiswa dalam kontribusi menyelesaikan persoalan yang ada di masyarakat. Kebermanfaatan keahlian yang dimiliki oleh mahasiswa dan dosen dapat berkontribusi melalu program abdimas yang bersentuhan dengan masyarakat dan stakeholders atau mitra. Dalam masa wabah ini, setiap masyarakat memiliki peran serta yang penting untuk bersama melindungi diri dan lainnya untuk mencegah dan menanggulangi penyebaran COVID-19 agar sama-sama terhindar dari bahaya wabah Covid-19. Kehadiran dosen dan mahasiswa melalui abdimas LPPM UTM di tengah masyarakat begitu dibutuhkan oleh masyarakat untuk membantu dalam menyelesaikan persoalan yang terjadi. Pandemi Covid-19 bisa dicegah dengan bekerja sama meningkatkan kewaspadaan dengan menerapkan protokol kesehatan dan pola perilaku hidup sehat untuk meningkatkan imunitas tubuh. Perlunya komunikasi yang membangun untuk memberikan kesadaran bersama kepada masyarakat bahwa pentingnya membantu dalam pencegahan mengenai pandemi Covid-19 (Silalahi, 2020).

\section{METODE}

Metode yang digunakan dalam pengabdian masyarakat ini merupakan salah satu program dari abdimas untuk berkontribusi secara langsung dalam upaya pencegahan virus Covid-19 yakni dengan cara :

1. Pembuatan dan pengembangan Teknologi tepat guna berupa pembuatan Masker, Pembuatan desinfektan, pembuatan hand sanitizer, pembuatan touchless handsanitizer dispenser, pembuatan tempat cuci tangan.

2. Konsepnya dengan melibatkan mahasiswa berpartisipasi dan berperan aktif bersama masyarakat dalam proses pembuatan dan pengembangan teknologi tepat guna serta menjadi bagian dari masyarakat dalam upaya pencegahan Covid-19 baik dengan memberikan edukasi kepada masyarakat desa dalam pemanfaatan kain bekas menjadi barang yang memiliki nilai lebih, pemanfaatan tanaman sekitar sebagai jamu tradisional atau juga sebagai hand sanitizer, penyuluhan pola hidup sehat. Tim pengabdian melakukan sosialisasi dalam mengajak masyarakat untuk pembuatan masker dari kain bekas. Masyarakat yang berpartisipasi membuat masker dari rumahnya masing-masing dan hasilnya di serahkan kepada masyarakat bisa digunakan sendiri, dijual, ataupun dibagikan kepada sesama.

3. Cara yang digunakan dalam melakukan pemberdayaan kelompok sasaran melalui daring, pelatihan langsung dengan 
memperhatikan protokol standar dari pemerintah, serta adanya kerjasama berupa MoU untuk tindak lanjut pengabdian.

\section{HASIL DAN PEMBAHASAN Pembuatan dan Pengembangan Teknologi Tepat Guna}

Touchless Hand Sanitizer Dispenser merupakan sebuah alat tepat guna yang didesain untuk mempermudah masyarakat dalam menggunakan hand sanitizer agar tidak perlu takut tertular virus Covid-19, karena tidak perlu menyentuh alat dalam penggunaannya. Alat ini dioperasikan dengan cara menginjak pedal dengan kaki. Touchless Hand Sanitizer Dispenser ini terbuat dari pipa yang ramah lingkungan dan bisa bertahan lama serta kuat untuk diinjak. Untuk merakit pipa menjadi Touchless Handsanitizer Dispenser terlebih dahulu potong pipa menjadi beberapa bagian dari pipa ukuran $1 \mathrm{dim}$ dan $3 / 4$ dim. Setelah selesai dipotong rakit pipa-pipa tersebut dengan tambahan bahan pipa L dan pipa $\mathrm{T}$ untuk mempermudah pembentukan.

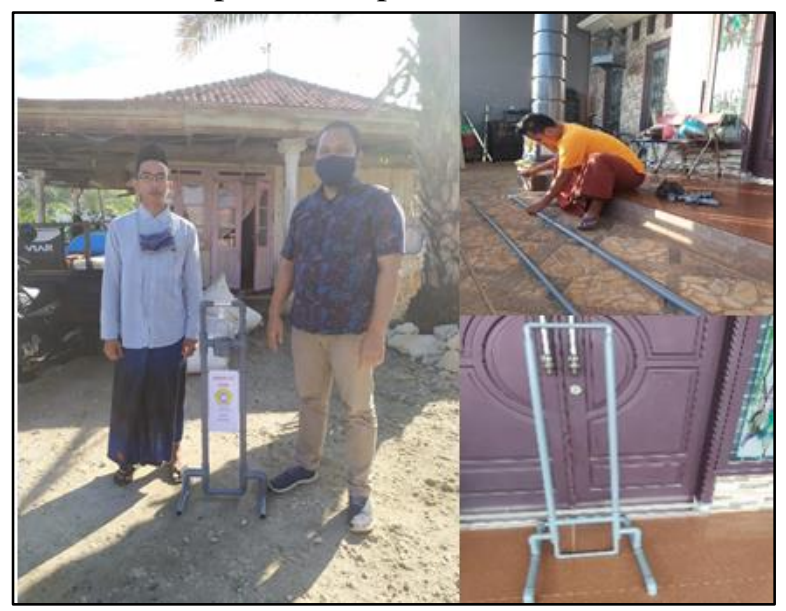

Gambar 1. Touchless Hand Sanitizer Dispenser

\section{Pembuatan Tempat Cuci Tangan dan Masker}

Teknologi tepat guna dalam menghindari meluasnya covid-19 juga dibuat berupa masker dan wastafel cuci tangan dari galon sebagai salah satu upaya perlindungan diri dari penyebaran virus covid-19. Melihat banyaknya masyarakat yang masih bepergian keluar rumah, maka dirasa perlu untuk adanya edukasi dan pembagian masker ke warga sekitar dan edukasi cuci tangan dengan sabun, kegiatan ini dilakukan untuk memberikan tempat cuci tangan di tempat umum dan tempat ibadah seperti pasar, musholla dan masjid.

Alat dan bahan yang digunakan dalam pembuatan masker adalah kain neoprane, jarum pentul, kertas template (rancangan) dan mesin jahit. Dalam proses pembuatan masker pertama kali dibuat template masker dari kertas yang sesuai ukuran kemudian membuat dua potongan kain yang sesuai dengan template yang sudah dibuat, lalu potong dengan rapi. Setelah dua potongan kain selesai, susun potongan kain menyerupai pantulan cermin, kemudian satukan kedua kain dengan dijahit. Masker nyaman dan elastis selesai dibuat dan siap digunakan. Sedangkan untuk pembuatan tempat cuci tangan menggunakan alat dan bahan ember bekas, kran air, pisau, lem, gunting, pipa, karet. Dari bahan tersebut dibuatlah tempat cuci tangan dengan cara melubangi ember, lalu kran air dimasukkan, selanjutnya dikasih lem. Selanjutnya kran dimasukkan kedalam lubang di ember kemudian dilem. Kemudian ujung kran dikasih selang lalu diikat dengan karet supaya tidak lepas. Lalu wastafel dari ember bekas siap digunakan.

\section{Pembuatan Desinfektan dan Hand Sanitizer Alami}

Pembuatan hand sanitizer ini menggunakan bahan alami yaitu daun sirih, lidah buaya, jeruk nipis, dan alkohol. Untuk perosedur pembuatannya, cuci semua bahan tersebut, kemudian rebus daun sirih selama 30 menit, dimana 20 menit pertama menggunakan api besar dan 10 menit terakhir dengan api kecil. Lalu saring dan pindahkan ke mangkuk / wadah (diamkan hingga dingin). Selanjutnya, bersihkan daging lidah buaya lalu di kocok menggunakan mesin blender hingga berbuih, lalu saring. Kemudian potong jeruk nipis, lalu peras dan saring airnya. Untuk langkah selanjutnya campur ketiga bahan tersebut dan aduk sampai benarbenar tercampur rata, lalu tuangkan alkoholnya. Kemudian masukkan kedalam botol spray.

Bahan utama yang digunakan untuk pembuatan hand sanitizer alami ini adalah cuka, cuka yang relatif mudah didapatkan, lalu air bersih, dan minyak esensial seperti kayu manis, cengkeh, kayu putih, atau jeruk nipis, namun dalam hal ini pembuatannya menggunakan jeruk nipis. Untuk meraciknya pun sangat mudah. Siapkan setengah cangkir cuka putih yang sudah disuling, setengah gelas air, lalu 12-24 tetes minyak esensial (jeruk nipis). Langkah selanjutnya campurkan cuka, air, dengan kombinasi minyak esensial tersebut (jeruk nipis). Kemudian kocoklah campuran tersebut dalam botol spray. Langkah terakhir simpan di tempat aman. Bila ingin digunakan, bersihkan dahulu 
media atau objek dari debu yang ada di rumah, sebelum disinfektan disemprotkan. Setelah itu, semprotkan dan bersihkan media atau objek tersebut dengan lap microfiber. Hasil pembuatan hand sanitizer dan desinfektan alami ini diberikan kepada masyarakat secara cuma - cuma, supaya digunakan dalam upaya preventif penyebaran Covid 19.

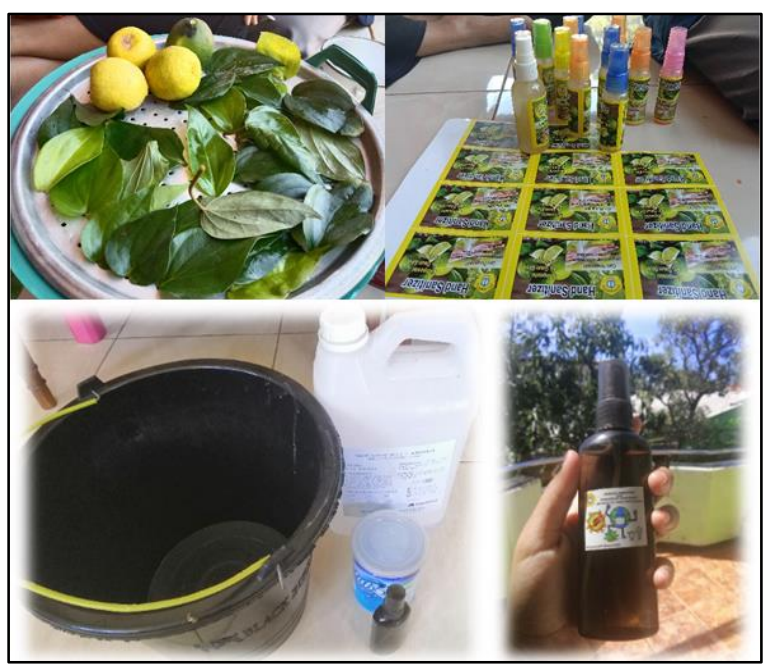

Gambar 2. Hand Sanitizer dari Bahan Alami

\section{KESIMPULAN}

Implementasi teknologi tepat guna sebagai upaya tindakan preventif penyebaran Covid-19 sangat dibutuhkan. Selain kesadaran dan ketaatan masyarakat kepada protokol kesehatan yang masih kurang diperlukan edukasi serta disediakan sarana dan pra sarana yang memadai. Dengan adanya pengabdian masyarakat ini dapat meningkatkan kesadaran masyarakat melalui edukasi serta pembuatan dan penyebaran teknologi tepat guna sehingga dapat berkontribusi pada pencegahan penyebaran Covid-19.

\section{DAFTAR PUSTAKA}

Arditama, E., \& Lestari, P. (2020). Jogo Tonggo : Membangkitkan Kesadaran Dan Ketaatan Warga Berbasis Kearifan Lokal Pada Masa Pandemi Covid-19 Di Jawa Tengah. Jurnal Pendidikan Undiksha, 8(2), 157-167. https://ejournal.undiksha.ac.id/index.php/JJPP

Karo, M. B. (2012). Perilaku Hidup Bersih dan Sehat ( PHBS ) Strategi Pencegahan Penyebaran Virus Covid-19. 1-4.

Melani, A. (2020). Update Corona COVID-19 Jawa Timur 3 Juli 2020: Pasien Positif 13.025, Sembuh 4.738 Orang. Liputan6. https://surabaya.liputan6.com/read/4295996/u pdate-corona-covid-19-jawa-timur-3-juli2020-pasien-positif-13025-sembuh-4738orang

Silalahi, A. (2020). Perubahan Pola Hidup Pada Situasi Covid-19 Adaptasi Pada Pola Hidup Normal Baru. Researchgate.Net, May, 1-10. https://doi.org/10.13140/RG.2.2.10961.76646

Sulaeman, S., \& Supriadi, S. (2020). Peningkatan Pengetahuan Masyarakat Desa Jelantik Dalam Menghadapi Pandemi Corona Virus Diseases19 (Covid-19). Jurnal Pengabdian UNDIKMA, I(1), 12-17. https://doi.org/10.33394/jpu.v1i1.2548

WHO. (2020). WHO Director-General's opening remarks at the media briefing on COVID-19$11 \quad$ March 2020. https://www.who.int/dg/speeches/detail/whodirector-general-s-opening-remarks-at-themedia-briefing-on-COVID-19---11-march2020

Widiyani, R. (2020). Latar Belakang Virus Corona, Perkembangan hingga Isu Terkini. https://news.detik.com/berita/d4943950/latar-belakang-virus-coronaperkembangan-hingga-isu-terkini

Yunus, N. R., \& Rezki, A. (2020). Kebijakan Pemberlakuan Lock Down Sebagai Antisipasi Penyebaran Corona Virus Covid-19. SALAM: Jurnal Sosial Dan Budaya Syar-I, 7(3), 227238. https://doi.org/10.15408/sjsbs.v7i3.15083

Zahrotunnimah, Z. (2020). Langkah Taktis Pemerintah Daerah Dalam Pencegahan Penyebaran Virus Corona Covid-19 di Indonesia. SALAM: Jurnal Sosial Dan Budaya Syar-I, 7(3), 247-260. https://doi.org/10.15408/sjsbs.v7i3.15103

Zamroni, M. (2020). Cara Indonesia Menanggulangi Corona Virus Disease-19 Melalui Peraturan Perundang-Undangan How Indonesia Against Corona Virus Disease 2019 With Laws and Regulations. 122-140. https://www.who.int/indonesia/news/novelcoronavirus/qa-for-public, 